\title{
Financial Crises in State Owned and Private Commercial Banks in Bangladesh: A Comparative Analysis
}

\author{
Kawsar Jahan \\ Dept. of Accounting \& Information Systems, University of Dhaka \\ Dhaka-1000, Bangladesh \\ Tel: 880-171-222-5773 E-mail: kjshumi@yahoo.com \\ Mohammod Akbar Kabir (Corresponding author) \\ Dept. of Economics, University of Dhaka, Dhaka-1000, Bangladesh \\ Tel: 880-171-285-9500Ｅ-mail: akbar_kabir03@yahoo.com
}

\begin{abstract}
Farjana Nur Saima
Faculty of Business and Social Science (BMA), Bangladesh University of Professionals

Chattogram, Bangladesh

E-mail: farjanamaisa@gmail.com
\end{abstract}

Md. Nasim Adnan

Internal Audit Dept., Bangladesh bank, Dhaka, Bangladesh

Email: nasim_1547@yahoo.co.uk

Received: April 08, 2019 Accepted: April 25, 2019 Published: May 15, 2019

doi:10.5296/ber.v9i2.14626 URL: https://doi.org/10.5296/ber.v9i2.14626

\begin{abstract}
Recently the performance of banking industry is one of the much talked issues in the history of Bangladesh. Predicting the factors of financial crises in banks is very much important as
\end{abstract}


this sector is facing a crises moment now. This study examined the driving factors of financial crises in banking sector using panel data consisted of five year observations (2012-2016) for each of 28 PCBs listed in Dhaka Stock Exchange (DSE) and 6 State-Owned Commercial Banks (SCBs). Financial crisis is measured by Altman's Z-score and Pooled Ordinary Least Square (Pooled OLS) has been applied to find out the factors necessary to condense financial crisis in banks. The study found that SCBs and listed PCBs in Bangladesh are facing financial crisis on the basis of Altman's Z-score model. Results of the analysis postulated that CRAR, NIIR and NINTR significantly contribute to lessen financial crisis in listed PCBs and also in SCBs. Therefore, the study suggests the regulatory authorities, including stakeholders and researchers to taking into account the findings of the study and to be more alert of the operations of SCBs and PCBs in order to steps forward the performance of this sector as well development of the country in the coming future.

Keywords: Financial crisis, Listed PCBs, SCBs, Pooled OLS, Altman's z-score

JEL Codes: G01, G21, G33

\section{Introduction}

Financial crisis (FC) is a term used to indicate a condition when promises to creditors of a company are broken or honored with difficulty. If FC cannot be relieved timely, it can lead an organization to bankruptcy. If an organization can detect FC timely and preventive measures can be taken, it can be come back to solvent position. To tackle financial crises situation, restructuring or merger take place (Hamid et al, 2016) and in case of banks, government and the central bank intervene with supportive actions. Altman and Hotchkiss (2006) defined FC of a firm by types of terms such as failure, default, insolvency and bankruptcy. Again Ross et al (2005) assumed FC occurs when a firm becomes unable to generate adequate operating cash flows to fulfill current liabilities and the firm is compelled to make remedial measures. It is an early indication of future bankruptcy. In case of banking industry whenever the capital adequacy ratio shortfalls, non-performing loan and lending risks increases, profitability falls down and inefficiency in management occurs, banks will likely to encounter FC. For example-in 1986 to 1991 Japanese banks experienced crisis due to huge non-performing loan; Lehman Brothers Holdings Incorporation, the US forth biggest investment bank, filed for bankruptcy in 2008 because of less liquid assets and capital shortfall (Hossain et al. 2017).

Banking industry serves as a fundamental source of financing for all other industries operating in the economy. Bank is the financial intermediary which borrows from the depositors and lends that money to others and playing a significant role in boosting economic performance of Bangladesh. According to World Bank statistics in 2013, around $34.1 \%$ of firms in Bangladesh have bank loans. Research says banking sector contributes to increase GDP and other sectors of the economy affects by banking sector. Research of South Asian Network on Economic Modeling (SANEM) claimed that due to present inefficiency of banking sector around 1\% of GDP is being lost and in amount this loss is estimated to be almost Tk. 10,000 core in the year 2016-17. Therefore it is essential to maintain a sound financial condition in the banking industry. 
At present banking sector of Bangladesh is facing a catastrophe moment due to increase of bad loans, weak corporate governance, enormous level of corruption, poor regulation and supervision and insignificant legal enforcement against defaulters (August 14, 2012, The Daily Star). Moreover, consistent bail outs of poor performing makes the situation more critical. According to Bangladesh bank quarterly report, (2017) NPL of SCBs increased than previous periods and stood at $26.52 \%$ of total loan in aggregate which is higher than other PCBs and Foreign Commercial Bank (FCBs). The reason of increasing amount of bad loans can be explained by the excessive amount of loan embezzlement in SCBs mainly through political influence occurring in the last couple of years; for instance- Sonali bank loan scandal of TK 3,500 crore associated with Hallmark Group during 2013, Basic Bank loan scandal of TK 4500 revealed in 2014, Janata bank loan scandal of Tk 5,500 crore associated with AnonTex Group during January 2018. Bangladesh Bank quarterly report (2017) showed Capital adequacy ratio of SCBs stood at $5.04 \%$ (minimum capital adequacy requirement $10 \%$ as per Basel III) in total lowered by $0.82 \%$ from the previous period. SCBs namely Sonali, Rupali, Janata and BASIC banks are facing capital deficit of more than Tk 76.26 billion in total despite the government providing recapitalization facility of Tk 102.72 billion from FY 2006-2017. Banks are now become more dependent on short term loan rather than long term loan, which are creating negative net working capital and liquidity problem. Some experts also attributed the year 2017 as the year of banking scams that were ever happened in Bangladesh. Different studies revealed that the loan scandals of Hallmark, Bismillah group, Basic Bank Ltd, Farmers Bank Ltd, Beximco Group, NRB Bank and a number of other big and small companies set the overall sector in financial crises. Scam one after another involving thousands of crores of taka in the country's financial sector over the years have jeopardized the economic progress and tarnishes the country's image aboard and increase the financial crises in the banking sector of Bangladesh. Experts are raising concern about the continuity of SCBs and of some PCBs in the upcoming days. Authority oblige new regulations in place time to time but nothing seems to work effectively yet. But it is well established that banks play a dominant role to grow both public and private sector economy. So, it is very important now to find out the root cause of financial crisis in the banking sector of Bangladesh for the development of the economy. Taking into account these scenario this study made an attempt to identify the factors driving financial crises of SCBs and listed PCBs in Bangladesh.

\section{Literature Review}

Financial crisis occurs when financial performance standards started to fall severely and an entity failed to cover up the losses. Financial crisis doesn't not show up all on a sudden rather it grows up gradually (Hilman, 2014). According to Hamid et al. (2016), distress related finance is an early signal to future collapse of an entity. Several micro and macro levlel factors act behind the financial crisis in banks. Several groups of studies tried to find out the causes of financial crisis in banks using different approaches. Hamid et al. (2016) quoted Telmoudi, Ghourabi, and Limam (2011) that managers can avoid the probable future losses by not making investment in the failing firms identified by the early financial distress signal. Researcher identified a number of bank specific financial factors as well as macroeconomic 
factors to be responsible for financial distress in banking industry.

To determine the factors associated with systematic bank crises in both the developing and developed countries, Demirgüç-Kunt and Detragiache (1997) conducted a study using sample data of 1981-94. Applying multivariate logit model, they found that low growth in weak macroeconomic environment, high inflation, high real interest rates, and vulnerability to balance-of-payments increase possibility of bank crisis. Moreover, Countries where law enforcement is weak and have explicit deposit insurance scheme were prone to risk also. So, they suggested policy makers should formulate deposit insurance scheme in such a way that will reduce moral hazard and vitalize banking industry. Similarly, Yauri et al. (2012) recommended bank governance should be improved in lieu of improving minimum CAR and asset quality to reduce distress threat.

In contrast Molina (2002) led an investigation to determine soundness of Venezuelan bank. The study considered several bank specific factors as well as macroeconomic factors as explanatory variables. It is found that equity to total assets, management efficiency, non-performing loan ratio, loan between interbank, residential and non-residential loan, public deposit, Other bank deposit, liquid assets, profitability ratio and bank size were significant elements to determine bank failure and survival whereas GDP, inflation and exchange rate are insignificant determinant.

Another study by Sahut and Mili (2011) considered several bank specific characteristics along with macroeconomic variables to estimate financial distress and merging probability in banks in Middle East and Northern Africa countries. Two separate logit models- consisting of distressed and non- distressed banks in the first model and only distressed bank some of which became merged in the second model were considered. Bank specific factors namely capitalization ratio, management quality and bank size have significant negative impact on distress probability whereas loan growth rate and earning ability have insignificant negative effect. No macroeconomic variable namely interest rate, exchange rate and CPI index rate comes out as significant determinants of financial distress.

Bank financial stability, measured by Z-score, in Gulf Cooperation Council (GCC) countries was investigated by Altaee et al. (2013) for all Islamic and conventional banks from the period 2010 to 2013. The sample period was separated into pre and post financial crisis period. The result of the analysis was financial stability in Shariah-compliant banks are not statistically difference from the financial stability in conventional banks during pre and post financial crisis. Moreover, Islamic banks are generally stronger than the conventional banks during the pre financial crisis. On the other hand, a similar recent study by Elbadri and Bektaş (2017) found financial stability in large Islamic bank is less than the large commercial banks whereas large Islamic bank and commercial banks tend to be financially stronger than their small counterparts.

A cross country study by Zhen-Jia-Liu (2015) examined the financial distress determinants employing logistic regression model. Total 772 banks from OECD, NAFTA, ASEAN, EU, NICS, G20 and G8 countries are taken as sample from the period 2002 to 2015. The study found significant negative association of capital ratios, interest income to interest expenses, 
non-interest income to non-interest expenses, return on equity and provisions for loan losses on bank failure whereas loan ratios, non-performing loans and fixed assets increases bank failure possibility. Similar cross country financial distress study on European banking sector was attempted by Baklouti et al. (2016). Total 147 banks from 18 countries were considered for the purpose of the study. Using logistic regression model, the study found among the governance variables only investor protection was significant determinants and CAMEL type characteristics variables were appeared insignificant in different periods except ROA which showed negative effects in pre-crisis period but became insignificant after the crisis; similar results found for bank size also. Besides, economic growth rate was found to have negative association with distress in banks.

In context of Bangladesh, Hossain et al. (2017) examined the bank specific factors causing bankruptcy based on the sample of 29 listed private commercial banks. Bankruptcy score was measured by Altman z-score and capital adequacy ratio, efficiency (measured by asset turnover), non-performing loan ratio (NPL), bank age were considered as explanatory variables. According to the results of system GMM and difference GMM applied in the study, CAR and efficiency positively affect Z-score but age and NPL negatively affect z-score. Only efficiency variable came out statistically insignificant.

The research observed financial crises in banks of Bangladesh and a scarcity of literature on financial crisis assessment in overall banking sector of Bangladesh. This study carried out on all SCBs and all listed PCBs in Bangladesh. Research expects that the outcome of the study will contribute literature and also help the regulators to formulate policy for overall banking sector in Bangladesh as these banks are undergoing serious financial problems.

\section{Research Methodology}

\subsection{Sample Design}

At present, there are 30 listed PCBs and 6 SCBs in Bangladesh. For the purpose of the study, secondary data have been collected from the available annual reports on the website of respective Banks. The study collected data from 28 listed PCBs and 6 SCBs over the period of 2012-2016. Thus, the sample consists of 140 bank-year observations for PCBs and 30 bank-year observations for SCBs. One listed private bank has been excluded from the sample due to non-availability of data. Rupali bank Limited is mainly a SCB and also listed in stock exchange and thus it has been included in the sample as a SCB not as a listed commercial bank.

\subsection{Description of Variables}

\subsubsection{Dependent Variable}

Realizing the consequences of bankruptcy risks, researchers and academicians have been attempted to develop different types of models. To predict the bankruptcy risk Altman Zscore (1968), Bankometer S-score, Ohlson (1980) O- score, Zmijewski (1984) X- score and many others models have been developed. Though no model can ensure hundred percent accuracy of prediction, a reasonable prediction can be made about the financial distress of an 
entity before the ultimate bankruptcy takes place. So far Altman Z-score model is proved to be best predictor of bankruptcy among all the models (Pradhan, 2014) and is widely used by previous empirical literatures.

The study have been measured FC in banks using Altman Z-score (Altman, 1993). Z-score helps to identify the possibility of financial crisis or default probability of a firm. It can be applied to any type of industry such as manufacturing, non-manufacturing firm including financial institutions. Previous literatures such as Altaee (2013), Qamruzzaman (2014), Badea and Matei (2016), Hamid et al. (2016), Kokkoris and Anagnostopoulou (2016), Hossain et al. (2017) and Elbadri and Bektaş (2017) applied Z-score to measure financial distress or stability in banks. As net working capital is not directly available due to non-classification of current assets and liabilities in financial statements of banks, net current liquidity gap has been used here instead. The study used operating profit of banks as EBIT. And book value of equity is used for SCBs which don't have market exposure and Market value of equity is used for listed PCBs traded in stock market. For financial institutions, the cut off points to predict bankruptcy are divided into three categories.

Safe zone: Altman Z-score greater than $2.6(Z>2.6)$ indicating Safe zone and states good position of firm with no financial problem.

Grey zone: Altman Z-score between 1.1 and $2.6(1.1<Z<2.6)$ indicating Grey zone. It declares the alarming situation. That is there is a likelihood of being distressed in near future. So firm should take necessary steps to avoid the situation.

Distress zone: Z-score less than $1.1(Z<1.1)$ indicating Distress Zone. It represents bad signal for the firm and the firm is most likely to be heading towards bankruptcy problem. Therefore urgent actions are needed to avoid financial crises (Altman, 1993).

The model is given below-

$$
Z=6.56 X_{1}+3.26 X_{2}+6.72 X_{3}+1.05 X_{4}
$$

Here, $\quad \mathrm{X}_{1}=$ Net Working Capital/ Total Assets

$$
\begin{aligned}
& \mathrm{X}_{2}=\text { Retained Earnings/ Total Assets } \\
& \mathrm{X}_{3}=\text { EBIT/ Total Assets } \\
& \mathrm{X}_{4}=\text { Book or Market Value of Equity/ Book Value of Total Liabilities }
\end{aligned}
$$

\subsubsection{Explanatory Variables}

To identify the factors driving financial crisis in both listed PCBs and SCBs, this study takes Capital to Risk Weighted Assets Ratio (CRAR), Loan Loss Provision Ratio (LLPR), Non-Interest Income Ratio (NIIR), Net Interest Income Ratio (NINTR), Total Loan to Total Assets Ratio (TLTA), Bank size, Gross Domestic Product growth rate (GDP) and Inflation rate (INF) as explanatory variables. The variables, their symbol, measurement and expected relationship are summarized in the table 1. 
Table 1. Description of Explanatory Variables

\begin{tabular}{|l|l|c|c|c|}
\hline \multicolumn{1}{|c|}{ Variables } & \multirow{2}{*}{ Symbol used } & Measurement & \multicolumn{2}{c|}{ Expected Relation } \\
\cline { 3 - 5 } & & Z-score & Bank Financial Crisis \\
\hline $\begin{array}{l}\text { Capital to Risk } \\
\text { Weighted Assets Ratio }\end{array}$ & CRAR & $\frac{\text { (Tier 1 + Tier 2) Capital }}{\text { Total Risk Weighted Assets }}$ & + & \\
\hline Loan Loss Provision Ratio & LLPR & $\frac{\text { Loan Loss Provision }}{\text { Total Loan and Advances }}$ & + & - \\
\hline Non-interest Income Ratio & NIIR & $\frac{\text { Non - interest Income }}{\text { Non - interest Expense }}$ & + & - \\
\hline Net Interest Income Ratio & NINTR & $\frac{\text { Net Interest Income }}{\text { Total Revenue }}$ & + & - \\
\hline $\begin{array}{l}\text { Total Loan to } \\
\text { Total Assets Ratio }\end{array}$ & TLTR & $\frac{\text { Total Loan and Advances }}{\text { Total Assets }}$ & - & + \\
\hline Bank SIZE & LN(SIZE) & Natural log of total assets & $-/+$ & + \\
\hline $\begin{array}{l}\text { Gross Domestic } \\
\text { Product Growth Rate }\end{array}$ & GDP & collected & + & - \\
\hline Inflation rate & INF & collected & - & + \\
\hline
\end{tabular}

\subsection{Research Hypotheses}

The study attempts to observe the comparative scenario of financial crisis in both SCBs and PCBs in Bangladesh. Therefore the title "Financial Crises in State Owned and Private Commercial Banks in Bangladesh: A Comparative Analysis" required to test the following hypothesis:

1. HA1: There is a significant relationship between the financial crises and CRAR in SCBs and PCBs in Bangladesh.

2. HA2: There is a significant relationship between the financial crises and LLPR in SCBs and PCBs in Bangladesh.

3. HA3: There is a significant relationship between the financial crises and NIIR in SCBs and PCBs in Bangladesh.

4. HA4: There is a significant relationship between the financial crises and NINTIR in SCBs and PCBs in Bangladesh.

5. HA5: There is a significant relationship between the financial crises and TLTR in SCBs and PCBs in Bangladesh.

6. HA6: There is a significant relationship between the financial crises and LN(size) in SCBs and PCBs in Bangladesh

7. HA7: There is a significant relationship between the financial crises and GDP in SCBs and PCBs in Bangladesh.

8. HA8: There is a significant relationship between the financial crises and INF in SCBs and PCBs in Bangladesh. 


\subsection{Model Specification and Analysis}

The following multiple regression model has been developed to find out the factors driving financial crisis. Same model has been considered separately for PCBs and SCBs.

$$
\begin{gathered}
\text { Z-score }_{i t}=\alpha_{0}+\beta_{0} \text { CRAR }_{i t}+\beta_{1} \text { LLPR }_{i t}+\beta_{2} \operatorname{NIIR}_{i t}+\beta_{3} \operatorname{NINTR}_{i t}+\beta_{4} \operatorname{TLTR}_{i t}+\beta_{5} L N\left(\operatorname{SIZE}_{i t}\right) \\
+\beta_{6} G D P_{i t}+\beta_{7} I_{i N}+\varepsilon_{i t}
\end{gathered}
$$

Where, subscript ${ }_{i t}$ denotes bank year observation, $\beta_{0,} \beta_{1}, \beta_{2}, \beta_{3}, \beta_{4}, \beta_{5}, \beta_{6}$, and $\beta_{7}$ are the coefficients for the independent variables and $\varepsilon$ represents error term.

To estimate the multiple regression model on financial crises in listed PCBs and SCBs, this study has applied Ordinary Least Square (OLS) estimation approach. Heteroscedasticity test has been done for both cases using Breusch Pagan test (1980) to see whether the variance of the error term is constant. The study did not found heteroscedasticity problem in regression model of PCBs and in SCBs.

\section{Results and Discussion}

\subsection{Z-Score}

This study considered 140 bank-year observations (5 years for 28 banks) for PCBs and 30 bank-year observations (5 years for 6 banks) for SCBs. Table 2 presents Average Z-score of Private Commercial Banks (PCBs) and State-owned Commercial Banks (SCBs).

Table 2. Average Z-score of PCBs and SCBs

\begin{tabular}{|l|l|l|l|}
\hline & Year & $\begin{array}{l}\text { Private Commercial } \\
\text { Banks (PCBs) }\end{array}$ & $\begin{array}{l}\text { State-owned Commercial } \\
\text { Banks (SCBs) }\end{array}$ \\
\hline Total Observations & & 140 & 30 \\
\hline Average Z-score: & 2012 & 0.2087 & 0.2684 \\
\cline { 2 - 4 } & 2013 & 0.4377 & 0.3445 \\
\cline { 2 - 4 } & 2014 & 0.3500 & 0.1811 \\
\cline { 2 - 4 } & 2015 & 0.3266 & 0.2260 \\
\cline { 2 - 4 } & 2016 & 0.3133 & 0.1328 \\
\hline
\end{tabular}

Source: Authors' estimation

Table 2 reflects that average Z-score of both PCBs and SCBs are below (1.1). It reveals both types of banks are financially unsound over the years 2012-2016 and possibility of serious bank crises is gradually rising. Therefore both PCBs and SCBs are most likely to be heading towards bankruptcy problem and necessary actions are needed to avoid financial crisis (Altman, 1993).

\subsection{Descriptive Statistics of SCBs and PCBs}

Table 3 represents summary statistics of independent variables used in the study. Mean value of CRAR for both SCBs and PCBs are respectively $8.15 \%$ and $8.25 \%$ indicates that SCBs and all listed PCBs are not maintaining the minimum capital adequacy regulation set by Bangladesh Bank. It reveals that banking sector violate of Basel III requirements of maintaining minimum $10.00 \%$ capital of total risk weighted assets. Moreover Negative 
minimum value of both also exposed the severe shortfall scenario of this sector.

Table 3. Descriptive Statistics of SCBs and PCBs

\begin{tabular}{|l|c|c|c|c|c|c|c|c|}
\hline \multirow{2}{*}{ Variable } & \multicolumn{5}{|c|}{ SCBs } & \multicolumn{4}{c|}{ PCBs } \\
\cline { 2 - 9 } & Mean & Standard Deviation & Min & Max & Mean & Standard Deviation & Min. & Max. \\
\hline CRAR & 0.081 & 0.121 & -0.290 & 0.272 & 0.082 & -1.081 & 0.154 & 0.198 \\
\hline LLPR & 0.109 & 0.054 & 0.033 & 0.214 & 0.052 & 0.015 & 0.447 & .0079 \\
\hline NIIR & 1.601 & 0.720 & 0.000 & 2.698 & 1.071 & 0.179 & 2.817 & 0.479 \\
\hline NINTIR & 0.001 & 0.151 & -0.272 & 0.349 & 0.226 & 0.049 & 0.463 & 0.090 \\
\hline TLTR & 1.669 & 0.392 & 1.020 & 2.682 & 1.234 & 1.011 & 1.724 & 0.114 \\
\hline LN (Size) & 12.568 & 1.033 & 10.395 & 13.998 & 12.050 & 9.414 & 14.246 & 0.648 \\
\hline GDP & 0.064 & 0.004 & 0.060 & 0.071 & 0.066 & 0.060 & 0.071 & 0.004 \\
\hline INF & 0.070 & 0.009 & 0.059 & 0.086 & 0.070 & 0.059 & 0.087 & 0.010 \\
\hline
\end{tabular}

Source: Authors' estimation

LLPR measured by loan loss provision to total loan are respectively $10.93 \%$ and $5.1 \%$ with standard deviation $5.49 \%$ and $7.87 \%$. Higher loan loss provision indicates lower asset quality of SCBs than PCBs. Mean value of NIIR measured by non-interest income to non-interest expense ratio is $160 \%$ and $107.11 \%$. But high dispersion of this ratio from mean value indicates that the industry average does not represent the other banks. Average value indicates listed SCBs are efficient enough to PCBs to generate income other than interest income to cover up the expenses other than interest expense.

Average value of NINTIR measured by net interest income to total revenue is $0.1 \%$ specifying poor earning ability of SCBs. Net interest spread is a primary determinant of bank profitability but unfortunately some SCBs are running with negative profitability evidenced by the minimum earning value of $-27.28 \%$. Whereas the mean percentage of net interest income to total revenue (NINTIR) is $22.59 \%$ meaning the earning ability of listed PCBs are good than SCBs. There are variations in earning ability among listed PCBs as the ratio ranges from $4.91 \%$ to $46.36 \%$ with standard deviation of $8.99 \%$.

Loan to deposit ratio, a measure of TLTR has an average rate respectively $166.73 \%$ and 123.4\% .Mean value specifies that SCBs and PCBs don't have liquidity risks.

The average size measured by total assets, of SCBs and the listed PCBs are 12.568601 and 12.0506 million respectively. The average GDP is $6.66 \%$ over the sample years. The minimum and maximum values of GDP are respectively $6 \%$ in 2013 and $7.10 \%$ in 2016 indicating GDP of Bangladesh is growing. The average mean value of inflation is $7.03 \%$ ranging between $5.92 \%$ in 2016 and $8.70 \%$ in 2012 meaning that the inflation rate is declining.

\subsection{Correlation Analysis between Explanatory Variables of SCBs and PCBs}

Pair wise correlation analysis has been done between independent variables and results presented in Table 4. The study observed that independent variable $\mathrm{LN}(\mathrm{Size})$ is highly correlated with NIIR(0.7725) and TLTR (0.7460) in SCBs. Whereas the correlation analysis in explanatory variables of PCBs showed that CRAR has high correlation with LLPR $(-0.8914)$ and $\mathrm{LN}($ Size $)(0.7560)$. Though the correlation is less 0.80 and the mean VIF value 
found is less than 10 ((LewisBeck, 1993; Gujarati, 2004) the study excluded two highly correlated (0.70) explanatory variables to execute regression analysis and get improve result. In regression model of SCBs the research dropped LN (Size) and TLTR from the regression model. And in PCBs the research dropped two independent variables LLPR and LN(Size). Moreover the study did not found any heteroskedasticity by applying Breusch Pagan test. The test did not reject the null hypothesis.

Table 4. Correlation Matrices of SCBs and PCBs

\begin{tabular}{|c|c|c|c|c|c|c|c|c|c|}
\hline & Explanatory Variables & CRAR & LLPR & NIIR & NINTIR & TLTR & LN(Size) & GDP & INF \\
\hline \multirow{8}{*}{ SCBs } & CRAR & 1.000 & & & & & & & \\
\hline & LLPR & 0.041 & 1.000 & & & & & & \\
\hline & NIIR & 0.041 & 0.502 & 1.000 & & & & & \\
\hline & NINTIR & 0.085 & -0.231 & -0.353 & 1.000 & & & & \\
\hline & TLTR & 0.426 & 0.390 & 0.571 & -0.534 & 1.000 & & & \\
\hline & LN(Size) & 0.470 & 0.587 & 0.772 & -0.412 & 0.746 & 1.000 & & \\
\hline & GDP & -0.002 & 0.019 & -0.227 & -0.108 & 0.038 & 0.143 & 1.000 & \\
\hline & INF & -0.082 & 0.168 & 0.064 & 0.487 & -0.035 & -0.256 & -0.375 & 1.000 \\
\hline \multirow{8}{*}{ PCBs } & CRAR & 1.000 & & & & & & & \\
\hline & LLPR & -0.891 & 1.000 & & & & & & \\
\hline & NIIR & 0.334 & -0.241 & 1.000 & & & & & \\
\hline & NINTIR & -0.030 & 0.016 & -0.653 & 1.000 & & & & \\
\hline & TLTR & 0.048 & -0.060 & 0.226 & -0.354 & 1.000 & & & \\
\hline & LN(Size) & 0.756 & -0.681 & 0.213 & 0.160 & -0.123 & 1.000 & & \\
\hline & GDP & -0.001 & -0.001 & -0.082 & 0.227 & -0.252 & 0.134 & 1.000 & \\
\hline & INF & 0.008 & -0.030 & 0.046 & -0.069 & 0.151 & -0.207 & -0.375 & 1.000 \\
\hline
\end{tabular}

Source: Authors' estimation

\subsection{Regression Analysis}

The regression results of Pooled OLS for both SCBs and PCBs are presented in the table 5. The value of $\mathrm{R}^{2}$ refers to the overall goodness of fit of the model and results show that the explanatory variables considered here can explain $66 \%$ variation in the Z-score of SCBs and $48 \%$ in case of PCBs.

Table 5. OLS Estimation and Test of Heteroschedasticity for Both SCBs and PCBs

\begin{tabular}{|l|l|l|}
\hline & SCBs & PCBs \\
\hline Variables & $\mathrm{z}$ & $\mathrm{z}$ \\
\hline & & \\
\hline CRAR & $5.027 * * *$ & $4.006^{* * *}$ \\
\hline & $(1.386)$ & $(0.451)$ \\
\hline LLPR & 1.749 & \\
\hline & $(2.636)$ & \\
\hline NIIR & $0.436 *$ & $0.573 * *$ \\
\hline & $(0.240)$ & $(0.247)$ \\
\hline NINTIR & $3.587 * *$ & $2.429 *$ \\
\hline & $(1.355)$ & $(1.310)$ \\
\hline GDP & -38.52 & -19.39 \\
\hline & $(36.14)$ & $(22.82)$ \\
\hline INF & -8.916 & -9.061 \\
\hline & $(19.00)$ & $(9.189)$ \\
\hline
\end{tabular}




\begin{tabular}{|l|l|l|}
\hline TLTR & & 0.637 \\
\hline & & $(0.779)$ \\
\hline Constant & 5.048 & -0.0631 \\
\hline & $(3.075)$ & $(2.158)$ \\
\hline & & \\
\hline Observations & 30 & 140 \\
\hline R-squared & 0.659 & 0.484 \\
\hline F Statistics & 7.090 & 20.800 \\
\hline Probability & 0.000 & 0.000 \\
\hline $\begin{array}{l}\text { Breusch-Pagan Test } \\
\text { H }: \text { Constant variance }\end{array}$ \\
\hline Chi-square & 0.140 & 2.090 \\
\hline Probability & 0.712 & 0.148 \\
\hline
\end{tabular}

Standard errors in parentheses. $* * *$ indicates significant at 1 per cent level $(\mathrm{p}<0.01)$. $* *$ indicates significant at 5 per cent level $(\mathrm{p}<0.05),{ }^{*}$ indicates that at 10 per cent level $(\mathrm{p}<0.1)$

Source: Authors' estimation

The regression results indicate capital to risk weighted assets ratio (CRAR) is a significant positive factor for financial crisis in both SCBs and PCBs. CRAR is an internal backup for banks to tackle the crisis moments. So, increase of this ratio significantly helps banks to offset any loan or long term investment loss. Hossain et al. (2017) also found CRAR as a significant bank specific factor of bankruptcy for PCBs in Bangladesh.

Loan Loss provision Ratio (LLPR) positively influences on financial crisis of SCBs. If this ratio goes on, Z-score of SCBs will decrease. Loan loss provision can act as an instrument to reduce the lending risk of banks and hence be used as the coverage for losses in distress situation (Zhen-Jia-Liu, 2015). But in case of SCBs, LLPR is seen to have positive influence on bank financial crisis meaning Z-core of SCBs will tend to reduce with one point increase in loan loss provision. Increase of provisioning may indicate poor asset quality driving the banks towards financial crisis. This result is consistent with Sahut and Mili (2011) and Baklouti et al. (2016). However, the relationship whether negative or positive is not seen to have significance at any of 0.01, 0.05 and 0.10 level in both cases.

Non-interest Income Ratio (NIIR), Net Interest Income Ratio (NINTR) has significant positive impact on financial crisis of both SCBs and PCBs. If NIIR and NINTR increase, Z score of banks also increases indicating less possibility of bank crisis. On the contrary, increase of TLTR ratio makes the Z-score be Higher or for PCBs is not significant. Hilman (2014) and Zhen-Jia-Liu (2015) found same results. Bank size, GDP and Inflation ratio are negatively associated with financial crisis in both cases of SCBs and PCBs. But these variables are not significant determinants for the banks financial crisis in Bangladesh. Molina (2002), Sahut and Mili (2011) and Halim and Khaled (2016) also found insignificant impact of GDP and Inflation on bank crisis.

\section{Conclusion}

This study is motivated by the desire to find out the factors that are the causes of financial crises in banking sector of Bangladesh. This will enable the financial sectors of Bangladesh 
to take corrective measures in appropriate time if they find themselves in distress position. Observing 30 observations for SCBs and 140 observations for PCBs over a 05 years period from 2012-2016 this study made a few conclusions. The conclusions were based on the outcomes of the descriptive statistics, correlation and regression analysis. The study found that within study period the overall banking sector of Bangladesh suffered by financial crises. The comparative study used Altman's Z-score as an indicator of financial crises and it is found that both SCBs and PCBs are in alarming position within the study period. The result of Ordinary Least Square (OLS) approach found that similar factor is responsible for financial crisis of both PCBs and SCBs in Bangladesh. The study postulates that Capital to risk weighted asset ratio (CRAR), non-interest income ratio (NIIR), net interest income ratio (NINTR) are significantly responsible for financial crises in listed PCBs and also in SCBs. LLPR, TLTR, GDP and INF are found to have insignificant relation with financial crisis in both cases. Future research can be done on this topic addressing the problem using advanced econometric tools and in using other measurement approach. Moreover, it would be interesting to find out the impact of corporate governance and other qualitative factors on financial crises in banking sector of Bangladesh.

\section{References}

Altaee, H. H. A., Talo, I. M. A., \& Adam, M. H. M. (2013). Testing the financial stability of banks in GCC countries: Pre and post financial crisis. International Journal of Business and Social Research, 3(4), 93-105.

Altman, E. I. (1968). Financial ratios, discriminant analysis and the prediction of corporate bankruptcy. The Journal of Finance, 23(4), 589-609.

https://doi.org/10.1111/j.1540-6261.1968.tb00843.x

Altman, E. I. (1993). Corporate financial distress and bankruptcy: a complete guide to predicting and avoiding distress and profiting from bankruptcy. New York: A Wiley and Sons.

Altman, E. I., \& Hotchkiss, E. (2006). Corporate Financial Distress and Bankruptcy (3 ${ }^{\text {rd }}$ ed.). John Wiley \& Sons, Inc., Hoboken, New Jersey.

Badea, I., \& Matei, G. (2016). The Z-score model for predicting periods of financial instability. Z-score estimation for the banks listed in Bucharest Stock Exchange. Finance-The challenges of the future, 16(18), 24-35.

Baklouti, N., Gautier, F., \& Affes, H. (2016). Corporate Governance and Financial Distress of European Commercial Banks. Journal of Business Studies Quarterly, 7(3), 75-96.

Demirgüç-Kunt, A., \& Detragiache, E. (1997). The Determinants of Banking Crises: Evidence from Developing and Developed Countries. IMF Working Papers.

http://dx.doi.org/10.5089/9781451947175.001

Elbadri, M., \& Bektaş, E. (2017). Measuring the Financial Stability of Islamic and Conventional Banks in Turkey. In N. ÖZATAC, \& K. GÖKMENOGLU. (Eds.), New Challenges in Banking and Finance. Springer Proceedings in Business and Economics. (pp. 115-137). Springer, Cham. https://doi.org/10.1007/978-3-319-66872-7_10 
Halim, S., \& Khaled, S. (2016). Islamic Banks and Financial Stability: Evidence from Bangladesh. Journal of Finance and Banking, 14(1\&2), 167-189.

Hamid, T., Akter, F., \& Rab, N. (2016). Prediction of Financial Distress of Non-Bank Financial Institutions of Bangladesh using Altman's Z Score Model. International Journal of Business and Management, 11(12), 261-270. http://dx.doi.org/10.5539/ijbm.v11n12p261

Hilman, I. (2014). The Bank Bankruptcy Prediction Models Based on Financial Risk (An Empirical Study on Indonesian Banking Crises). International Journal of Business, Economics and Law, 4(2), 1-16.

Hossain, M. S., Abedin, M. T., \& Sen, K. K. (2017). Bankruptcy and Bank Specific Factors: A Panel Analysis. 1st International Conference on Business \& Management, University of Dhaka, Bangladesh, 282-286.

Kokkoris, I., \& Anagnostopoulou, M. (2016). Altman Z-Score Bankruptcy Analysis in the Greek Banking Sector. International Corporate Rescue, 13(1), 59-68.

Molina, C. A. (2002). Predicting bank failures using a hazard model: the Venezuelan banking crisis. Emerging markets review. 3, 31-50. https://doi.org/10.1016/S1566-0141(01)00029-2

Ohlson, J. A. (1980). Financial ratios and the probabilistic prediction of bankruptcy. Journal of Accounting Research, 18(1), 109-131. https://doi.org/10.2307/2490395

Qamruzzaman, M. (2014). Predicting bankruptcy: Evidence from private commercial banks in Bangladesh. International Journal of Financial Economics, 2(3), 114-121.

Ross, S. A., Westerfield, R. W., \& Jaffe, J. (2005), Corporate Finance, International Edition, 7th ed, McGraw-Hill, New York.

Sahut, J. M., \& Mili, M. (2011). Banking distress in MENA countries \& the role of mergers as a strategic policy to resolve distress. Economic Modeling, 28(2), 138-146.

https://doi.org/10.1016/j.econmod.2010.09.017

Telmoudi, F., Ghourabi, M. E. L., \& Limam, M. (2011). RST-GCBR - Clustering - Based RGA-SVM Model for Corporate Failure Prediction. Intelligent Systems in Accounting, Finance and Management, 18(2-3), 105-120. https://doi.org/10.1002/isaf.323

White, H. (1980). A heteroskedasticity-consistent covariance matrix estimator and a direct test for heteroskedasticity. Econometrica, 48(4), 817-838. https://dx.doi.org/10.2307/1912934

Yauri, N. M., Musa, J., \& Kaoje, N. A. (2012). Bank Recapitalisation in Nigeria: Resuscitating Liquidity or Forestalling Distress. International Journal of Business and Social Science, 3(10), 298-305.

Zhen-Jia-Liu. (2015). Cross-country study on the determinants of bank financial distress. Revista de Administração de Empresas, 55(5), 593-603.

https://dx.doi.org/10.1590/s0034-759020150510

Zmijewski, M. E. (1984) Methodological issues related to the estimation of financial distress 
prediction models. Journal of Accounting Research, 22, 59-82.

https://doi.org/10.2307/2490859

\section{Copyright Disclaimer}

Copyright for this article is retained by the author(s), with first publication rights granted to the journal.

This is an open-access article distributed under the terms and conditions of the Creative Commons Attribution license (http://creativecommons.org/licenses/by/3.0/). 